\title{
Follow-up study on indoor radon levels in Irish schools after a National School Survey and remediation programme
}

\author{
Gillian Gunning', Marta Fuente'2, Robert Gunning,', Stephanie Long³, Eric Finch' and \\ Mark Foley ${ }^{2}$ \\ 'School of Physics, Trinity College Dublin, Dublin, Ireland; ${ }^{2}$ School of Physics, National University of Ireland Galway, \\ Ireland; ${ }^{3}$ Environmental Protection Agency, Clonskeagh Square, Dublin, Ireland
}

\section{Abstract}

Background: A National Survey of Radon in Irish Schools was carried out by the Department of Education and the Environmental Protection Agency (EPA) (formerly the Radiological Protection Institute of Ireland) between 1998 and 2004. Then, a remediation programme was developed and implemented in the schools with elevated radon levels.

Objectives: To determine the durability of the remediation systems 10-17 years post-installation and to study the effect of radon awareness on follow-up programmes, radon retests were performed in 16 schools that had some form of remediation implemented.

Design: The schools were chosen based on the data of the National Survey for Irish Schools and the post-remediation survey. A total of 276 rooms were tested for radon using CR-39 etched track detectors supplied by the EPA. Short questionnaires were given to the school principals to gather information about the level of radon awareness, remediation maintenance and retesting policies.

Results: An increasing trend in the radon concentration with time was found in some schools. Potential factors contributing to this rise are lack of maintenance, lack of follow-up testing programmes and knowledge lost due to staff turnover. The results showed that $26 \%$ of the rooms which had remediation installed had risen to above the Department of Education's reference level for schools of $200 \mathrm{~Bq} / \mathrm{m}^{3}$ again and 10\% to above $400 \mathrm{~Bq} / \mathrm{m}^{3}$. Through case studies and questionnaires, radon awareness in schools was observed to be correlated with an ability to maintain radon concentrations below the reference level. Although the National Survey of Radon in Irish Schools is to be commended for its exhaustive completeness, many schools in this project were unaware of the remediation system installed. Only $15 \%$ of the schools in this study remember or have records of regularly checking or servicing their remediation systems.

Conclusions: Retesting for radon is crucial in indicating where remediation methods are less effective or have failed. A follow-up programme to retest for radon and to ensure maintenance of remediation systems should be implemented.

Keywords: radon; schools; radon awareness; remediation; follow-up testing

$\mathrm{R}$ adon gas is considered the main source of ionising radiation exposure for the general population. It is a radioactive gas product of the decay of radium $\left.{ }^{(26} \mathrm{Ra}\right)$, which belongs to the decay series of the uranium $\left.{ }^{238} \mathrm{U}\right)$ and is present in soils and rock of the Earth's crust. Radon originating from the ground can permeate through the soil and penetrate the indoor space of buildings, where it tends to accumulate resulting in a health risk. Recognised as the second leading cause of lung cancer by the World Health Organisation (WHO), indoor exposure to radon gas is responsible for around 300 lung cancer cases per year in Ireland $(1,2)$. To minimise indoor radon concentrations, there are various prevention and remediation techniques, often these remediation techniques are dependent on the gas flow through the granular fill materials used in the building construction (3-7). Measuring radon concentrations is key to controlling radon levels in any type of building $(8,9)$.

A survey of radon concentrations in schools was conducted in Ireland during the years 1998 and 2004 by the then Department of Education and Science (DES), with the assistance and guidance of the Environmental Protection Agency (EPA; formerly the Radiological Protection Institute of Ireland, RPII) (10). The project was called the National Survey of Radon in Irish Schools (hereafter referred to as the National School Survey or the NSS) and was carried out in over $95 \%$ of the primary and post-primary schools in Ireland. Radon concentration 
was measured in a total of 3,826 schools and 38,531 rooms using CR-39 etched track detectors. The average radon concentration found was $93 \mathrm{~Bq} / \mathrm{m}^{3}$. A total of 984 schools presented radon concentrations over $200 \mathrm{~Bq} / \mathrm{m}^{3}$ in 3,028 rooms ( $7.9 \%$ ) and 329 schools over $400 \mathrm{~Bq} / \mathrm{m}^{3}$ in 800 rooms $(2.1 \%)(11)$.

Following the NSS, an experienced UK remediation consultant was contracted to implement a strategy for reducing the radon concentration in all rooms that were greater than $200 \mathrm{~Bq} / \mathrm{m}^{3}$, and local radon contractors implemented the strategy (12). The reference concentration of $200 \mathrm{~Bq} / \mathrm{m}^{3}$ was used because at the time the reference levels in Ireland were $200 \mathrm{~Bq} / \mathrm{m}^{3}$ for dwellings and $400 \mathrm{~Bq} / \mathrm{m}^{3}$ for workplaces, and the view was taken by the DES that 'children should expect the same level of protection while at school as in the home' $(10,11,13,14)$.

A reference level is defined to regulate indoor radon exposure, but it does not define a rigid boundary between safety and danger (1). The WHO advises setting a reference level for radon gas as low as possible and proposed $100 \mathrm{~Bq} /$ $\mathrm{m}^{3}(1,15)$. The 2013/59/EURATOM BSS Directive, mandatory since February 2018, advises that all member states of the European Union shall establish national reference levels not exceeding $300 \mathrm{~Bq} / \mathrm{m}^{3}$ for dwellings, buildings with public access and workplaces (16). The Directive did not state explicit advice for schools but classified them as types of workplaces or buildings with public access. The cautious approach adopted by the DES in setting the $200 \mathrm{~Bq} / \mathrm{m}^{3}$ reference level for schools during the NSS was warranted. In 2014, the National Radon Control Strategy (NRCS) for Ireland recommended retaining this reference level for schools (17). A radon concentration of $200 \mathrm{~Bq} / \mathrm{m}^{3}$ results in an equivalent dose of $5 \mathrm{mSv}$ per year for a dwelling, assuming an occupancy time of 7,000 $\mathrm{h}$ (18). For schools, the occupancy is assumed to be a minimum of $1,000 \mathrm{~h}$, which at a radon concentration of $200 \mathrm{~Bq} / \mathrm{m}^{3}$ would result in an equivalent dose of $0.7 \mathrm{mSv}$ per year.

The remediation systems implemented were, in general, an active sump where concentrations were over $400 \mathrm{~Bq} /$ $\mathrm{m}^{3}$, and for concentrations between $200-400 \mathrm{~Bq} / \mathrm{m}^{3}$, passive ventilation, such as window trickle vents or wall vents, was installed. Summaries of the project and the detailed remediation techniques implemented were reported, and a post-remediation survey was conducted in many schools to confirm whether the remediation was successful $(11,12)$. In the cases where remediation was not successful, but radon levels were in the range of 200-400 $\mathrm{Bq} / \mathrm{m}^{3}$, no further remediation was conducted as the results were below the statutory workplace reference level. However, in the school rooms with radon concentrations above $400 \mathrm{~Bq} / \mathrm{m}^{3}$ post-remediation, further remediation was implemented and then retested for confirmation.

Several countries have undertaken school radon testing programmes, and Clouvas et al included a summary of the studies done in Europe when publishing their work on a Greek school survey (19). The Irish NSS is considered as one of the most comprehensive undertaken in Europe due to its size and detail, which makes it ideal for a follow-up remediation study.

This article presents a follow-up radon survey conducted in a selection of schools from the NSS, with the main aim of investigating the durability of the remediation systems installed and determining the importance of follow-up programmes.

\section{Materials and methods}

The survey was conducted in a total of 16 schools that had remediation implemented after the NSS, of which 10 are located in a high radon area (HRA) as defined by the radon map for Ireland (20). Three schools were located in County Dublin, six schools in County Galway, four schools in County Kerry and three schools in County Wicklow. The schools were chosen by the percentage of rooms that had radon concentrations above $200 \mathrm{~Bq} / \mathrm{m}^{3}$, as measured in the NSS, in order to obtain a sufficient data set to make conclusive comparisons of rooms with radon remediation. In total, $77 \%$ of the rooms measured in this follow-up survey were greater than $200 \mathrm{~Bq} / \mathrm{m}^{3}$.

The radon detectors used for the survey were CR-39 etched track detectors, supplied and analysed by the EPA. Detectors were placed and collected in person to allow in situ examination of the rooms and to avoid non-returning of the detectors when posted, as the NSS reported a $26 \%$ non-return rate of detectors (11).

The survey was conducted in two phases. Phase one was a pilot survey undertaken in six schools that were contacted and asked to participate in a radon review process initiated by the EPA and DES. CR-39 etched track detectors were placed in each occupied ground floor room of the schools and collected after a 3-month period (March-June). Short questionnaires were given to the principals to determine the level of radon awareness asking:

- Whether the school had a radon retesting policy and if so to provide the results

- If any maintenance had been carried out on the currently installed remediation

- If any retrofitting had been done to the school

- If new extensions have been tested for radon or fitted with any remediation.

One of the issues highlighted in the pilot survey was the lack of consistency of room names over periods of time. This made it difficult to correlate the rooms listed in the NSS to the current rooms tested. Subsequently, for phase 2 of this study, schools were chosen from a report compiled by the radon adviser in the NSS. The report detailed 
the radon concentration in each room and the type of remediation implemented, which together with school photographs and floor-plans made it possible to correlate rooms for comparison.

The second phase was conducted the following year on an additional 10 schools. CR-39 etched track detectors were placed in person and left for 6 months (JanuaryJune). The remediation works were inspected where possible, and similar to phase one, a questionnaire was completed.

\section{Results and discussion}

\section{Results from the follow-up study}

The radon measurements from the NSS and the post-remediation survey for the 16 schools tested in this study were provided by the EPA. The summary statistics for the three stages of the survey, the initial NSS, the post-remediation survey (completed between 1998 and 2004) and the follow-up survey completed in 2014-2015, are presented in Table 1. No school reported a concentration lower than $10 \mathrm{~Bq} / \mathrm{m}^{3}$ in the follow-up study, as this is the lower limit of detection of the CR-39 etched track detectors supplied by the EPA (11). Seasonal correction factors were not applied to these results. At the time of this survey and until 2018, seasonal correction factors were derived from measurements carried out in homes and therefore were only applied to home measurements as per the EPA protocol.

The number of rooms measured in the three stages is different; some rooms initially measured in the NSS were not measured post-remediation because the radon concentration initially recorded was below $200 \mathrm{~Bq} / \mathrm{m}^{3}$. In the follow-up study, additional rooms that were not measured

Table 1. Summary of radon surveys' statistical data results

\begin{tabular}{lccc}
\hline & $\begin{array}{c}\text { National } \\
\text { school survey }\end{array}$ & $\begin{array}{c}\text { Post-remediation } \\
\text { survey }\end{array}$ & $\begin{array}{c}\text { Follow-up } \\
\text { survey }\end{array}$ \\
\cline { 2 - 4 } & $\begin{array}{c}250 \text { rooms } \\
(16 \text { schools })\end{array}$ & $\begin{array}{c}209 \text { rooms } \\
(16 \text { schools })\end{array}$ & $\begin{array}{c}276 \text { rooms } \\
(16 \text { schools })\end{array}$ \\
\hline AM $\pm \mathbf{~ S E ~}\left(\mathrm{Bq} / \mathrm{m}^{3}\right)$ & $520 \pm 33$ & $79 \pm 5$ & $1 \mathrm{II} \pm 8$ \\
ASD $\left(\mathrm{Bq} / \mathrm{m}^{3}\right)$ & 525 & 69 & 136 \\
GM $\left(\mathrm{Bq} / \mathrm{m}^{3}\right)$ & 370 & 58 & 60 \\
GSD $\left(\mathrm{Bq} / \mathrm{m}^{3}\right)$ & 2 & 2 & 3 \\
Median $\left(\mathrm{Bq} / \mathrm{m}^{3}\right)$ & 356 & 57 & $5 \mathrm{I}$ \\
Range & 3,809 & 489 & 687 \\
$(\mathbf{m i n}, \mathbf{m a x})$ & $(3,93,848)$ & $(10,499)$ & $(10,697)$ \\
$\left(\mathrm{Bq} / \mathrm{m}^{3}\right)$ & & & \\
\hline Note:AMis & & &
\end{tabular}

Note: AM is the arithmetic mean of the radon concentration with standard error (SE), ASD is the arithmetic standard deviation, GM is the geometric mean of the radon concentration and GSD is the geometric standard deviation. The range indicates the difference between the minimum and maximum radon concentrations. in the NSS were tested, possibly due to unreturned detectors in the initial survey or because they were built in the interim.

Synnott et al. (5) found that the nationwide arithmetic mean (AM) in schools was $93 \mathrm{~Bq} / \mathrm{m}^{3}$, but here a higher $\mathrm{AM}$ of $520 \mathrm{~Bq} / \mathrm{m}^{3}$ is reported; this is due to the bias in selecting schools with an elevated radon concentration. The NSS post-remediation AM was $79 \mathrm{~Bq} / \mathrm{m}^{3}$, meaning that remediation was successful. In the follow-up study, the $\mathrm{AM}$ has risen to $111 \mathrm{~Bq} / \mathrm{m}^{3}$ which indicates that some remediation methods are not working as efficiently as when first installed or that some have failed. By looking at the geometric mean (GM), post-remediation and follow-up values are almost the same, and similarly, the median reported for each stage correlates quite closely with the respective GM.

The arithmetic standard deviation (ASD) is a parameter indicative of the data set dispersion, and it is valuable to identify possible outliers of high radon concentration that can skew the AM. The ASD for the follow-up survey is $136 \mathrm{~Bq} / \mathrm{m}^{3}$ indicating a large spread of values in the data set. Consequently, it can be deduced that some of the remediation works failed in time, resulting in outliers in the data.

A total of 224 rooms measured in the NSS were correlated with the rooms tested in this follow-up study. About 52 of the rooms measured in the follow-up study could not be correlated with the rooms in the NSS, and this was due to the building of new rooms, the combining of rooms or rooms that were not measured in the NSS as a result of unreturned detector. Table 2 compares the data from the NSS to the correlated and un-correlated data from the follow-up survey with respect to three reference levels; $200 \mathrm{~Bq} / \mathrm{m}^{3}$ is the reference level for dwellings and schools in Ireland, $300 \mathrm{~Bq} / \mathrm{m}^{3}$ is the reference level for workplaces following the European Union Directive 2013/59/Euratom and $400 \mathrm{~Bq} / \mathrm{m}^{3}$ is the former Irish workplace reference level $(13,14,16)$. The rooms for the correlated and uncorrelated data are different, but their close agreement confirms the trend for the percentage of rooms exceeding the reference levels.

Table 2. Percentage of rooms exceeding the reference level in the NSS and the follow-up survey

\begin{tabular}{lccc}
\hline \multirow{2}{*}{$\begin{array}{l}\text { Reference } \\
\text { level }\end{array}$} & NSS (\%) & \multicolumn{2}{c}{ Follow-up survey } \\
\cline { 3 - 4 } & 77 & $\begin{array}{c}\text { Correlated } \\
\text { rooms (\%) }\end{array}$ & $\begin{array}{c}\text { Uncorrelated } \\
\text { rooms (\%) }\end{array}$ \\
\hline$>200 \mathrm{~Bq} / \mathrm{m}^{3}$ & 60 & 8 & 14 \\
$>300 \mathrm{~Bq} / \mathrm{m}^{3}$ & 44 & 5 & 9 \\
$>400 \mathrm{~Bq} / \mathrm{m}^{3}$ & & 5 & 5 \\
\hline
\end{tabular}

Note:The correlated rooms column refers to those rooms tested in the NSS which were matched with rooms tested in the follow-up study and similarly for the uncorrelated rooms column. 
The follow-up survey also highlighted 8 rooms with radon measurements above the $200 \mathrm{~Bq} / \mathrm{m}^{3}$ reference level that did not have a previous radon measurement, possibly because of unreturned detectors.

Post-remediation radon tests were not conducted in all the schools remediated, and hence, post-remediation measurements were not available for all the rooms tested in the follow-up survey, and it is not possible to be certain that the 224 correlated NSS and follow-up survey rooms were below $200 \mathrm{~Bq} / \mathrm{m}^{3}$ following the remediation works. A data set of 146 rooms could be correlated for the three stages of the survey: NSS, post-remediation and follow-up, of which 129 were above $200 \mathrm{~Bq} / \mathrm{m}^{3}$ during the NSS and had remediation implemented. Data are summarised in Table 3.

Based on data from Table 3, the remediation works implemented after the NSS were successful in reducing radon concentration below $400 \mathrm{~Bq} / \mathrm{m}^{3}$ for the totality of the rooms tested and below $200 \mathrm{~Bq} / \mathrm{m}^{3}$ in a $97 \%$ of the rooms measured. The follow-up survey conducted 10-17 years after the remediation shows that $26 \%$ of the rooms are above $200 \mathrm{~Bq} / \mathrm{m}^{3}$ reference level and $10 \%$ of the rooms are above $400 \mathrm{~Bq} / \mathrm{m}^{3}$, indicating failures of remediation works with time.

After the National Survey of Irish Schools, it was reported that radon concentrations above $200 \mathrm{~Bq} / \mathrm{m}^{3}$ were measured in 3,028 school rooms, and radon concentrations above $400 \mathrm{~Bq} / \mathrm{m}^{3}$ were measured in 800 rooms (11). Based on these data and extrapolating data from Table 3 regarding the follow-up survey, it is predicted that approximately 790 rooms are currently above the Irish reference level for schools (see Table 4). This prediction disregards the $5 \%$ of schools not tested during the NSS and schools built since the NSS. However, the DES now require all newly built schools to be tested for radon, and where the reference level is exceeded, remediation must be carried out by the building contractor. Consequently, the number of new schools with radon concentrations above the reference level is likely to be very low.

\section{Radon awareness in schools}

In order to ascertain the level of radon awareness in the schools, a summary of the results from the short

Table 3. Number of rooms exceeding the reference level in the NSS, post-remediation and follow-up survey

\begin{tabular}{lccc}
\hline $\begin{array}{l}\text { Reference } \\
\text { level }\end{array}$ & $\begin{array}{c}\text { Correlated } \\
\text { NSS, no. of } \\
\text { rooms }\end{array}$ & $\begin{array}{c}\text { Correlated } \\
\text { post-remediation } \\
\text { survey, no. of } \\
\text { rooms }\end{array}$ & $\begin{array}{c}\text { Correlated } \\
\text { follow-up } \\
\text { survey, no. } \\
\text { of rooms }\end{array}$ \\
\hline$>200 \mathrm{~Bq} / \mathrm{m}^{3}$ & 129 & 5 & $34(26 \%)$ \\
$>300 \mathrm{~Bq} / \mathrm{m}^{3}$ & 106 & 2 & $23(18 \%)$ \\
$>400 \mathrm{~Bq} / \mathrm{m}^{3}$ & 79 & 0 & $13(10 \%)$ \\
\hline
\end{tabular}

Note:The correlated rooms column refers to those rooms tested in the NSS which were matched with rooms tested in the follow-up study. questionnaires was given to the school principals, presented in Table 5. From the first contact with schools during the follow-up survey, it was noticed that radon awareness and radon interest varied widely; $63 \%$ of the schools had retested for radon since the end of the NSS programme, of which $60 \%$ are located in HRAs of Co. Kerry and Co. Galway. The level of awareness due to media attention, EPA awareness campaigns and journal publications is likely to contribute to these schools implementing a retesting programme $(20,21)$. Among the remediated schools, only $15 \%$ of these had a protocol in place for the maintenance of the installed remediation.

Some schools had built extensions, and among them, it was noticed that a high percentage (83\%) had installed a radon remediation system. Upon further investigation, it was found that in each circumstance, window trickle vents were installed. These are a ventilation requirement set out in the building regulations, and therefore, a remediation system was not intentionally installed (22). Of the schools which had built extensions, only two had measured the radon concentration in the new extension, and again, these were located in HRAs of Co. Kerry, showing the influence of radon awareness in the protection against radon.

Fifty per cent of the schools tested in the follow-up survey had been energy retrofitted since the NSS, involving window replacement, wall insulation, roof replacement or heating system replacement. Among the seven schools where an increased radon concentration was found in the follow-up survey, four of them had been retrofitted after the NSS. It is difficult to state with certainty the impact of the retrofitting modifications in the radon concentrations, due to the small data set and the time lapse between post-remediation and the follow-up survey. However, recent studies have shown the correlation of various energy retrofit programmes and increased indoor radon concentrations $(23,24)$. Also, remediation failure would

Table 4. Prediction for number of rooms above the reference level in Irish schools currently, based on the results of the follow-up survey and NSS (11)

\begin{tabular}{lcc}
\hline Reference level & $\begin{array}{c}\text { NSS (1998-2004), } \\
\text { no. of rooms }\end{array}$ & $\begin{array}{c}\text { Prediction, } \\
\text { no. of rooms }\end{array}$ \\
\hline$>200 \mathrm{~Bq} / \mathrm{m}^{3}$ & 3,028 & $790(26 \%)$ \\
$>400 \mathrm{~Bq} / \mathrm{m}^{3}$ & 800 & $80(10 \%)$ \\
\hline
\end{tabular}

Table 5. Summary of radon awareness questionnaire results

\begin{tabular}{lc}
\hline & Percentage of schools \\
\hline Retesting programme & 63 \\
Remediation system maintained & 15 \\
Retrofitting installed since NSS & 50 \\
Remediation installed in extensions & 83 \\
\hline
\end{tabular}


have to be excluded as the cause of the radon concentration increase before it could be attributed to the energy retrofit works.

\section{Case studies}

To investigate the influence of radon awareness campaigns and radon programmes in schools, three schools are analysed separately as case studies. The first school (case study 1) is in a HRA with a limited radon programme in place considering retesting only, the second school (case study 2) is in a HRA with a comprehensive radon programme including retesting and remediation maintenance. Lastly, the third school (case study 3 ) is in a low radon area with no radon programme in place.

\section{Case study I}

The school is a large secondary school in a HRA of Co. Kerry that was remediated after the NSS. Remediation works consisted of the installation of eight sub-slab pressurisation sumps as advised by the radon contractor. The principal indicated that, to his knowledge, maintenance was not carried out on the remediation works but radon measurements were conducted in 2013 and the results were provided. Figure 1 shows a boxplot of the radon concentration in the school at the different stages. The mean radon concentration reported in the NSS was $580 \mathrm{~Bq} / \mathrm{m}^{3}$, and two remediation attempts were needed to reduce radon concentration below the reference level, achieving a mean radon concentration of $80 \mathrm{~Bq} / \mathrm{m}^{3}$ (post-remediation 2). However, the radon measurement conducted in 2013 (Intermediate 1) and the follow-up survey measurement reported an increase in the mean radon concentration over the reference level, reaching a mean radon concentration of $430 \mathrm{~Bq} / \mathrm{m}^{3}$ in 2015 .

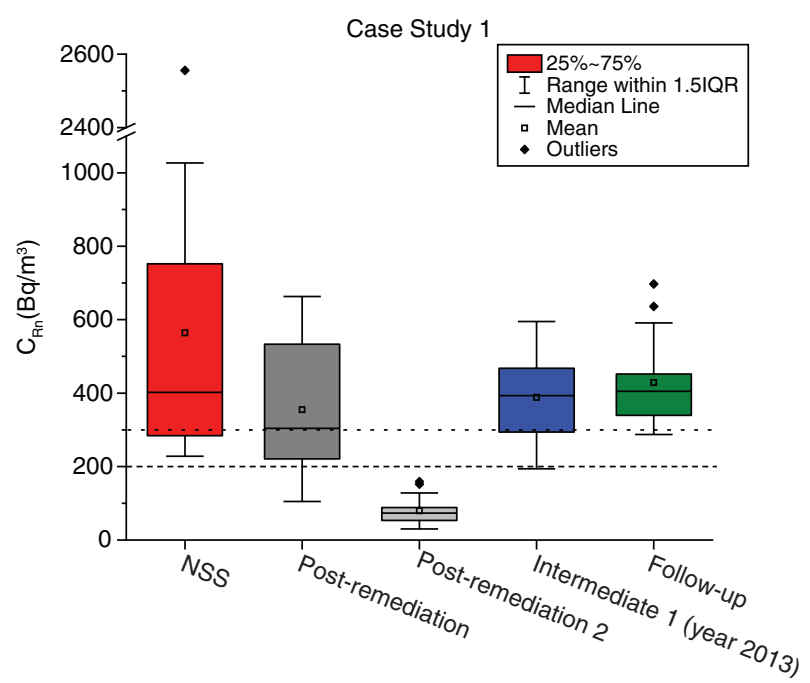

Fig. 1. Boxplot of radon concentration measurements for case study 1 - Co. Kerry.

\section{Case study 2}

The school is a medium size secondary school located in a HRA of Co. Kerry remediated after the NSS. Remediation works consisted of the installation of seven sub-slab depressurisation sumps. The principal indicated that a local radon adviser was contracted by the school for the maintenance of the remediation works and that radon measurements were conducted on two occasions after the NSS in years 2011 and 2012. The results of both measurements were provided. Figure 2 shows a boxplot of the radon concentration in the school at the different stages. Mean radon concentration reported in the NSS was $813 \mathrm{~Bq} / \mathrm{m}^{3}$, and after the remediation, it was reduced to $70 \mathrm{~Bq} / \mathrm{m}^{3}$. In 2011, it was found that radon levels had risen (Intermediate 1) and the school repaired the remediation system in the affected rooms. The following year radon tests were repeated (Intermediate 2) and confirmed the success of the repair works, achieving a mean radon concentration of $124 \mathrm{~Bq} / \mathrm{m}^{3}$, well below the reference level. The follow-up survey measurements reported a slight increase in the mean radon concentration but still below the reference level for schools.

\section{Case study 3}

The third school is a school located in a low radon area of Co. Wicklow. It was remediated after the NSS by installing, according to the radon consultants' advisory report, three radon sumps to serve six rooms and permanent trickle vents in the rooms above $200 \mathrm{~Bq} / \mathrm{m}^{3}$. These were confirmed at the time of detector placement, but one sump was found unintentionally switched off and did not seem to be functioning (no noise when it was turned on). The principal was not aware of the remediation system installed, and thus, maintenance was not carried out and intermediate measurements were not conducted. A new room had been

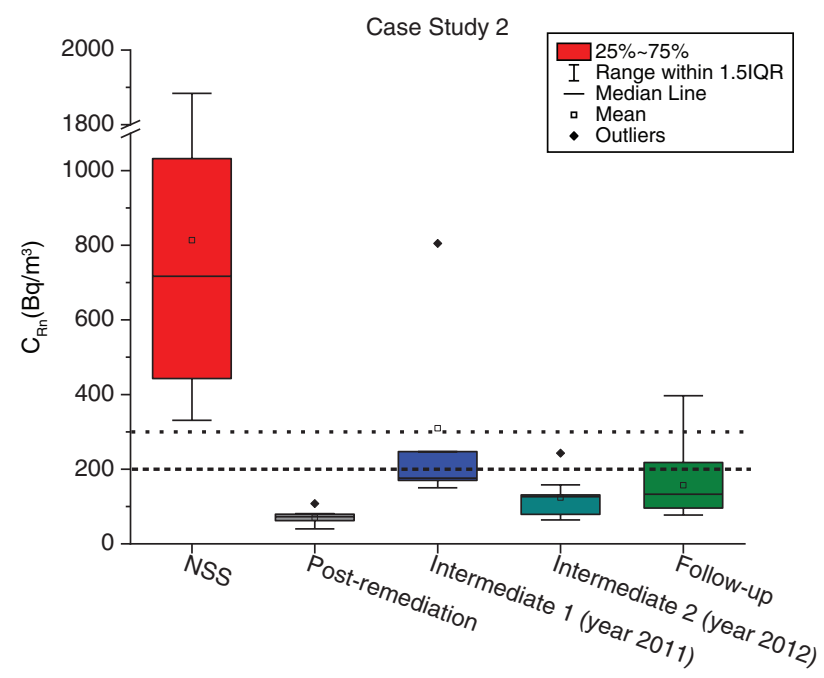

Fig. 2. Boxplot of radon concentration measurements for case study 2 - Co. Kerry. 


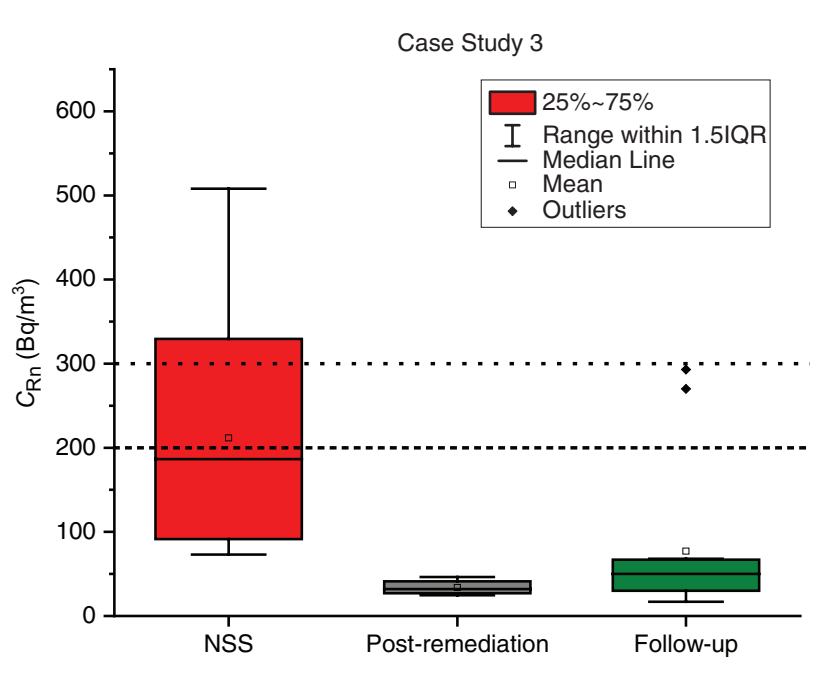

Fig. 3. Boxplot of radon concentration measurements for case study 3 - Co. Wicklow.

added to the school, and trickle vents were present in accordance with building regulations (11). Figure 3 shows a boxplot of the radon concentration in the school at the different stages. Mean radon concentration reported in the NSS was $212 \mathrm{~Bq} / \mathrm{m}^{3}$, and after the remediation, it was reduced to 34 $\mathrm{Bq} / \mathrm{m}^{3}$. In the follow-up survey, it was found that mean radon concentration doubled, reaching $77 \mathrm{~Bq} / \mathrm{m}^{3}$, and that radon concentration in two rooms was above the reference level as a result of the mentioned sump failure.

During the school visits, most school principals showed a high degree of interest in radon and facilitated the follow-up survey. The case studies presented point out the significance of radon awareness in schools and the key role of radon programmes in keeping levels below the reference level radon concentrations in schools. In particular, case study 1 highlights the importance of schools being actively involved in radon remediation maintenance and in responding to high radon levels to prevent radon exposure of the staff and students.

\section{Conclusions}

A follow-up survey was conducted in Irish schools to test indoor radon concentrations after they were remediated 10-17 years previously following a NSS. The study was motivated by the aim to determine the durability of the remediation works and the importance of radon awareness and structured follow-up programmes. The follow-up survey was conducted in a sample of 16 schools. Radon concentrations were tested using CR-39 etched track detectors in a total of 276 rooms, and questionnaires were given to the school principals to determine the level of radon awareness.

From the results of the follow-up survey, an increasing trend in the radon concentration was found in schools because of the lack of maintenance and follow-up testing programmes in place. In rooms where remediation was installed, it is seen that $26 \%$ of the rooms have risen to above the reference level of $200 \mathrm{~Bq} / \mathrm{m}^{3}$ and $10 \%$ are now above 400 $\mathrm{Bq} / \mathrm{m}^{3}$. It is difficult to accurately extrapolate these results; however, if one was to do so, it would lead to the prediction that currently 790 school rooms are potentially above 200 $\mathrm{Bq} / \mathrm{m}^{3}$ within the 3,826 schools originally tested.

Radon awareness was assessed through case studies and short questionnaires. It was observed that a correlation existed between the level of awareness and the ability to maintain radon concentrations under the reference level. As a consequence of media attention and publications, HRAs demonstrated higher radon awareness leading to a higher retesting rate, which is a unique finding from this study. Despite this, media attention is not constant and should not be relied on in isolation to raise radon awareness.

The questionnaires revealed that only $15 \%$ of the schools tested in the follow-up survey had checked or serviced their remediation systems. Case study 1 illustrated what can happen when remediation works fail and radon concentrations return to elevated levels. Students and staff were possibly exposed to radon concentrations over $400 \mathrm{~Bq} / \mathrm{m}^{3}$ because no action was taken to maintain the remediation system. As a direct result of this study, the EPA now recommend retesting every 5 years of any workplace or home that has been remediated.

Measuring for radon is essential not only to determine radon levels but also to check the effectiveness of remediation systems with time. Policies for schools to retest for radon and to ensure maintenance of remediation systems should be implemented to respond to the rising radon concentration trend reported in this follow-up study.

\section{Acknowledgements}

The authors would like to thank the staff and teachers from the Department of Education and the staff from the Environmental Protection Agency for their invaluable assistance and cooperation, in particular, Michael Murray, Alison Dowdall, David Fenton and John Smith.

\section{Conflict of interest and funding}

The authors have no conflict of interest. The authors have not received any funding or benefits from industry or elsewhere to conduct this study.

\section{References}

1. World Health Organization (2009). Handbook on indoor radon. A public health perspective. Geneva: WHO Press.

2. NRCS (2019). National radon control strategy year 4 report. Technical report. Dublin: EPA publication.

3. Hung LC, Goggins J, Fuente M, Foley M. Characterisation of specified granular fill materials for radon mitigation by soil depressurisation systems. Construct Build Mater 2018; 176: 213-27. doi: 10.1016/j.conbuildmat.2018.04.210 
4. Hung LC, Goggins J, Fuente M, Foley M. Investigation of subslab pressure field extension in specified granular fill materials incorporating a sump-based soil depressurisation system for radon mitigation. Sci Total Environ 2018; 637: 1081-97. doi: 10.1016/j.scitotenv.2018.04.401

5. Fuente M, Rábago D, Goggins J, Fuente I, Sainz C, Foley M. Radon mitigation by soil depressurisation case study: radon concentration and pressure field extension monitoring in a pilot house in Spain. Sci Total Environ 2019; 695: 133746. doi: 10.1016/j.scitotenv.2019.133746

6. Fuente M, Muñoz E, Sicilia I, Goggins J, Frutos B, Foley M. Investigation of gas flow through soils and granular fill materials for the optimisation of radon soil depressurisation systems. J Environ Radioact 2019; 198: 200-9. doi: 10.1016/j.jenvrad.2018.12.024

7. Hung LC, Goggins J, Meier P, Monahan E, Foley M. An investigation of a passive opened top-end pipe as an alternative solution for passive soil depressurisation systems for indoor radon mitigation. Sci Total Environ 2020; 748: 141167. doi: 10.1016/j. scitotenv.2020.141167

8. Gunning GA, Murray M, Long SC, Foley MJ, Finch EC. Inter-comparison of radon detectors for one to four week measurement periods. J Radiol Protect 2016; 36(1): 104. doi: 10.1088/0952-4746/36/1/104

9. Fuente M, Rabago D, Herrera S, Quindos L, Fuente I, Foley $\mathrm{M}$, et al. Performance of radon monitors in a purpose-built radon chamber. J Radiol Protect 2018; 38: 1111-27. doi: 10.1088/1361-6498/aad969

10. Synnott H, Fennell G, Pollard D, Colgan PA, Hanley O, O'Colmain M, et al. Radon in Irish primary and post-primary schools. The results of a national survey. Technical Report RPII04/2. Dublin: Radiological Protection Institute of Ireland; 2004.

11. Synnott H, Hanley O, Fenton D, Colgan PA. Radon in Irish schools: the results of a national survey. J Radiol Protect 2006; 26(1): 85-96. doi: 10.1088/0952-4746/26/1/005

12. Synnott H, Hanley O, Fenton D, Colgan PA. Radon remediation in Irish schools. Health Phys 2007; 92(1): 50-7. doi: 10.1097/01. HP.0000234038.25522.98

13. Stationery Office (2002). Radon in existing buildings. Corrective options. Technical report. Dublin: Department of the Environment and Local Government, Stationery Office.
14. Stationery Office (2000). Radiological Protection Act, 1991 (ionising radiation) order. Statutory Instrument 125 of 2000. Dublin: Department of Public Enterprise. Government Publications Office.

15. Zeeb H. International Radon Project. Survey on radon guidelines, programmes and activities. Technical Report WHO/HSE/ RAD/07.01. Geneva: World Health Organization; 2007.

16. EURATOM. Council directive 2013/59/EURATOM of 5 December. Office J Eur Union (No L13) Official Journal of the European Union 2013.

17. National Radon Control Strategy. Report. Department of Environment, Community and Local Government. Dublin: EPA publication; 2014.

18. Sources and effects of ionizing radiation, annex B. Report to the General Assembly, with Scientific Annexes. United Nations: United Nations Scientific Committee on the Effects of Atomic Radiation (UNSCEAR); 1993.

19. Clouvas A, Xanthos S, Takoudis G. Indoor radon levels in Greek schools. J Environ Radioact 2011; 102: 882-5. doi: 10.1016/j. jenvrad.2011.05.001

20. Fennell GM, Mackin JS, Madden A, McGarry AT, Duffy JT, O'Colmain M, et al. Radon in dwellings. The Irish national radon survey. Technical Report RPII-02/1. Radiological Protection Institute of Ireland. Dublin: EPA publication; 2002.

21. Organo C, Murphy, P. The Castleisland radon survey - follow-up to the discovery of a house with extremely high radon concentrations in County Kerry (SW Ireland). J Radiol Protect 2007; 27(3): 275-85. doi: 10.1088/0952-4746/27/3/002

22. Department of the Environment, Heritage and Local Government (DEHLG). Building regulation 1997, technical guidance document $\mathrm{C}$ - site preparation and resistance to moisture. Technical report. Dublin: Department of the Environment, Heritage and Local Government; 1997.

23. Milner J, Shrubsole C, Das P, Jones B, Ridley I, Chalabi Z, et al. Home energy efficiency and radon related risk of lung cancer: modelling study. BMJ 2014; 348: f7493. doi: 10.1136/bmj.f7493

24. Collignan B, Le Ponner E, Mandin C. Relationships between indoor radon concentrations, thermal retrofit and dwelling characteristics. J Environ Radioact 2016; 165: 124-30. doi: 10.1016/j. jenvrad.2016.09.013 